\title{
What Determines the Choice of Tourist Destination? The Case of Denmark
}

\author{
Susanne Jensen \\ Idea2action \\ Houvej 13, DK-9500 Hobro, Denmark \\ E-mail: sus@idea2action.dk \\ Gert Tinggaard Svendsen \\ Aarhus University, Department of Political Science \\ Bartholins Allé 7, Building 1350, DK-8000 Aarhus C, Denmark \\ E-mail: gts@ps.au.dk
}

Received: Nov. 22, 2017 Accepted: Nov. 30, $2017 \quad$ Published: Dec. 14, 2017

doi:10.5296/bmh.v5i2.12302 URL: http://dx.doi.org/10.5296/bmh.v5i2.12302

\begin{abstract}
What determines the choice of tourist destination? Based on the comprehensive tourist surveys by VisitDenmark in 2004, 2008 and 2011, we find that both Danes and tourists from countries close to Denmark attach great importance to safety, but it is also important for nationalities such as Americans and Japanese. Furthermore, tourists staying at hotels and youth hostels ascribe less weight to safety than tourists using other accommodation forms. Finally, returning tourists ascribe more weight to safety than first-time tourists.
\end{abstract}

Keywords: Safety, Tourism, Destination, VisitDenmark's tourist survey, Denmark, Scandinavia 
"The safety of the people shall be the highest law."

Marcus Tullius Cicero

\section{Introduction}

We know that a number of factors determine tourists' choice of holiday destination. So where to go? Quo vadis? In the literature, authors have listed decision and motivation factors such as availability of activities, affordability, travel costs, loyalty, geographical proximity, availability of cultural and entertainment attractions, nature experiences, relaxation, and meeting new people (Page \& Connell, 2006; Sirakaya \& Woodside, 2005; Weaver \& Lawton, 2006). A strong driver for a person's wish to travel is the opportunity for exploration; however, at the same time, another strong but conflicting driver is at play: the question of the tourist's personal safety when travelling to destinations where he or she may not be familiar with social rules for interaction, safety issues and so on (Jensen \& Svendsen, 2016; Svendsen \& Svendsen, 2016; Bianchi, 2015; Brandt \& Svendsen, 2010; Canally \& Timothy, 2007; Goeldner \& Ritchie, 2006).

Our contribution to this literature on safety and destination choice among tourists is therefore to analyse how important safety is by going into depth with one single case, namely the case of Denmark. In the line of this, we investigate what characterise tourists for whom the safety factor is important. Thorough analysis of this single case is possible because of our access to a unique dataset from VisitDenmark's tourist survey conducted among Danish and foreign leisure tourists in Denmark in 2004, 2008 and 2011. Thus, the main research question is: What determines the choice of tourist destination? In the following, Section 2 first presents the topic of safety in a tourist destination perspective. Section 3 discusses the method and the data. Next, the empirical results are presented in Section 4. Finally, Section 5 gives the conclusion.

\section{Safety and the Choice of Destination}

In tourism research motivation has for long been seen as an important topic because the concept places focus on the role of tourist behaviour for tourism development, and furthermore it may be seen as the driving force for actions (Crompton, 1979; Pearce \& Lee, 2005). As mentioned earlier, we concentrate in this study on one of the motivation factors, namely the safety aspect.

What matters for the tourists' choices are the perceived risks of travelling to and staying at a destination (Garg, 2015; Yang et al., 2015). Perceived risks may take many forms in tourism. It may include crime, disease, weather, physical, equipment failure, cultural barriers, terrorism, war and political crises (Pennington-Gray \& Schroeder, 2013; Pizam \& Mansfeld, 2006; Yang et al., 2015). In recent literature on the safety of tourists, there has been a tendency to focus on major terrorism events such as 9/11 or bombings at Egyptian tourist resorts, which have caused huge safety problems for the tourism industry and a feeling of fear and danger among tourists when they travel (Kozak et al., 2007; Page \& Connell, 2006; Mansfeld \& Pizam, 2006; Wilks \& Page, 2003). Similarly, issues relating to safety have been formed in the wake of other recent events such as the Arab Spring and the attacks in Tunisia 
and Paris.

The risks related to minor everyday situations, however, also matter for tourists' feeling of safety and sense of security. This issue is less highlighted in the literature even though many investigations of destination choice include one or several indicators of safety and security (Pearce, 2005; Pisonero, 2015; Hsu et al., 2009). As observed by Tasci \& Boylu (2010, p. $179)$, "...safety and security perception and its influence on tourist behaviour have received limited empirical attention from researchers".

\section{Methods and Data}

In this section, we present the data and methods used for analysing the case of Denmark. The study is based on a conclusive research design applying descriptive research to examine the relation between the motivation factor safety and the characteristics of tourists visiting Denmark (Malhotra, Birks, \& Wills, 2012). The analysis uses quantitative data from the face-to-face based Tourist Survey conducted by VisitDenmark; the official Danish Tourist Council. The Tourist Survey covers the main forms of tourism in Denmark and includes information on tourism behaviour and the characteristics of tourists. The survey is among other thing used for estimating the economic and employment impact of tourism in Denmark.

Data used in our analysis was collected in 2004, 2008 and 2011 and includes the five main forms of commercial leisure accommodation in Danish tourism: hotels, holiday centres, youth hostels, campsites and rented holiday homes. In all, these forms of accommodation account for about 40.0 million nights in 2011 and a turnover of 25.3 billion Danish kroner (approx. 3.7 billion US\$) (VisitDenmark, 2013). This should be compared to a total number of nights of 137.9 million in 2011 and a turnover of 82.4 billion Danish kroner (approx. 12.2 billion US\$) (VisitDenmark, 2013). The total number of nights and turnover includes business tourists, nights at sailing boats, visiting friends and relatives, owners' own use of their holiday homes, same-day tourists (both leisure and business) and some less important groups. For most of these groups, the decision and motivations factors may be seen as quite different than for the pure leisure tourism included in the analysis.

The dataset includes interviews with 35,779 Danish and foreign tourists in Denmark (11,200 interviews in 2004, 12,749 interviews in 2008 and 11,830 interviews in 2011). Interviews were conducted at the tourists' place of accommodation according to a quota plan produced by VisitDenmark and Statistics Denmark on the basis of previous information on the number of nights and previous consumer investigations. This ensures that the investigation is representative for the tourists visiting Denmark. Answers from 24,111 respondents were applicable for our analysis. This number includes only leisure tourists while business tourists were not asked for their motives to come to Denmark. The quantitative approach and the high number of respondents enable statistical generalisations of results.

The main question in the tourist survey that we use for this study is the following: For what reason or reasons did you choose Denmark as the destination for your holiday? The respondents had the possibility to answer yes or no to twenty-two pre-defined motives, such as: people in general, nature, a child-friendly environment, the price level, attractions, 


\section{Macrothink}

possibility to angle or play golf, and so on. One of the options was whether tourists feel safe about staying in Denmark. We combine the question about motives for choosing Denmark as a destination with other information from the survey. Thus, in the following, we will analyse the relationship between safety and the factors characterising tourists showing some descriptive statistics (tables 1-4). Furthermore, we create a multivariate model to clarify which factors are the most important in explaining safety as a motivation for travelling to Denmark (table 5).

\section{Results}

The following section presents the results of the study. Table 1 shows that one of the most important motives for foreign and Danish tourists to choose Denmark as a holiday destination is the feeling of safety. Safety is selected by $61.1 \%$ of the tourists in $2011,59.1 \%$ in 2008 and by $59.3 \%$ in 2004 as a contributory factor in choosing Denmark as a destination. This ranks safety as the most important motive for choosing Denmark as a destination among the 22 possibilities in the survey in 2011 and as the second most important factor in 2008 and the third most important factor in 2004. In 2011, "safety" was ranked before "nature", which was mentioned by $58.2 \%$ of the tourists, "good accommodation opportunities" (57.9\%), "tidy country" (53.9\%), "people in general" (50.1\%) and "interesting cities" (47.2 \%). In 2008, safety was ranked second after "nature", which was mentioned by $67.5 \%$ of the tourists but before "tidy country" (58.0\%), "people in general" (47.0\%), "opportunities to enjoy Danish food" (38.7\%) and "child-friendly" (38.4\%). In 2004, "safety" was ranked third, surpassed by "nature" (72.9 \%) and "tidy country" (61.0\%) but ranked before "people in general" (48.0\%), "child-friendly" (41.0\%) and "attractions" (40.0\%). 
Table 1. Nationality of tourists, percentage motivated by safety\#, ranking of safety, size of the market, number of nights

\begin{tabular}{|c|c|c|c|c|c|c|c|c|}
\hline \multirow[t]{2}{*}{$\begin{array}{l}\text { Segment of the } \\
\text { marketo }\end{array}$} & \multicolumn{3}{|c|}{\begin{tabular}{|l} 
Percentage \\
safety $(\%)$
\end{tabular}} & \multicolumn{3}{|c|}{$\begin{array}{l}\text { Ranking of the safety } \\
\text { motive (1-22) }\end{array}$} & \multirow{2}{*}{\begin{tabular}{|l}
$\begin{array}{l}\text { Size of the } \\
\text { market, } \\
\text { inhabitants) }{ }^{\&}\end{array}$ \\
2011
\end{tabular}} & \multirow{2}{*}{\begin{tabular}{|l}
$\begin{array}{l}\text { No. of nights } \\
\text { in Denmark } \\
(1,000)\end{array}$ \\
2011
\end{tabular}} \\
\hline & 2004 & 2008 & 2011 & 2004 & 2008 & 2011 & & \\
\hline Denmark (ref) & 54.0 & 50.3 & 45.6 & 2 & 2 & 4 & 5.6 & 19,837 \\
\hline Belgium & 43.6 & $35.1^{*}$ & $69.5^{*}$ & 4 & 4 & 2 & 11.0 & 78 \\
\hline Finland & 55.9 & 68.0 & 36.3 & 2 & 1 & 7 & 5.4 & 124 \\
\hline France & $32.7 *$ & 48.1 & 51.9 & 6 & 3 & 3 & 65.0 & 137 \\
\hline Germany & $64.1 *$ & $68.6^{*}$ & $75.8^{*}$ & 3 & 3 & 4 & 81.8 & 13,203 \\
\hline Netherlands & 58.7 & $55.5^{*}$ & $73.8^{*}$ & 3 & 3 & 4 & 16.7 & 965 \\
\hline Italy & 61.8 & 60.0 & 55.6 & 2 & 3 & 3 & 60.6 & 147 \\
\hline Japan & 59.6 & 69.2 & 57.9 & 3 & 1 & 3 & 128.1 & 54 \\
\hline Norway & $70.4 *$ & $63.9 *$ & $67.6^{*}$ & 1 & 1 & 1 & 4.9 & 2,131 \\
\hline Poland & 62.1 & 58.3 & 48.4 & 2 & 2 & 4 & 38.1 & 83 \\
\hline Switzerland & 45.2 & 55.8 & 55.5 & 3 & 1 & 2 & 7.9 & 129 \\
\hline Spain & $35.4 *$ & 53.3 & 39.4 & 6 & 4 & 4 & 46.7 & 96 \\
\hline Sweden & $67.2 *$ & $58.8^{*}$ & $60.1^{*}$ & 1 & 1 & 1 & 9.4 & 1,363 \\
\hline UK & 48.6 & 49.1 & 51.8 & 4 & 2 & 3 & 62.5 & 335 \\
\hline USA & 54.5 & $61.4^{*}$ & $58.3^{*}$ & 1 & 1 & 2 & 308.7 & 234 \\
\hline Other Europe & 53.9 & 56.4 & 51.2 & 4 & 1 & 3 & & 772 \\
\hline Other world & $38.5^{*}$ & $70.7^{*}$ & $58.9 *$ & 3 & 1 & 3 & & 286 \\
\hline Total & 59.3 & 59.1 & 61.1 & 3 & 2 & 1 & & 39,974 \\
\hline
\end{tabular}

Notes. \#: Question in the tourist survey: For what reason or reasons did you choose Denmark as the destination for your holiday? $\mathrm{a}$ : Answers specified on the most important nationalities for Danish tourism. \&: Japan and USA: data from $2010 .{ }^{*} \mathrm{~A} \chi^{2}$ test reveals that for nationalities marked with an asterisk, the percentage motivated by safety is significantly different than for the reference group Denmark.

Sources: Estimations based on VisitDenmark's tourist survey 2004, 2008 and 2011; VisitDenmark, 2013; EUROSTAT, 2013; United Nations, 2014.

Table 1 also shows that there are differences between which weights various nationalities ascribe to safety when choosing destination for their vacation. For nationalities such as Norwegians and Swedes, safety is ranked as the most important factor for choosing Denmark as a destination in 2011, whereas tourists from the United Kingdom and France only rank this factor on the third places in 2011 and even worse in 2004. Of the French, only half mentions safety as important for choosing Denmark as a destination in 2011, while Germans rate safety as of highest importance in $2011(75.8 \%)$, Japanese in $2008(69.2 \%)$ and Norwegians in $2004(70.4 \%)$.

The countries with the highest percentage motivated by safety are the countries closest to Denmark; that is, Norway, Sweden and Germany but tourists from countries such as USA and 
Japan, which are geographically far from Denmark also weight safety high. However, the statistical $\chi^{2}$-test reveals that in 2011 , only for the Dutch, Norwegians, Swedes, Germans, Belgians, Americans and tourists from the residual "other world" is the percentage motivated by safety significantly different compared to the reference group Denmark.

It is important to note that the investigation only includes tourists who have actually chosen Denmark as a destination. The hypothetical question may have been answered differently by the tourists who did not travel to Denmark than by the tourists who already made the decision. Furthermore, tourists that do not find safety important may decide to go to other destinations than Denmark, resulting in a bias to overestimate the importance of safety for potential tourists to Denmark.

An interesting factor to analyse is whether the knowledge of and familiarity with Denmark has an influence on the weight tourists ascribe to safety. The expectation is that new tourists to Denmark attach importance to safety because they are travelling to a country they are not familiar with. Thus, the feeling of safety may be relatively important. In contrast to our expectations, safety is weighed significantly higher by the tourists who have visited Denmark before than by tourists who are staying in Denmark for the first time in the last five years (see Table 2). The result contrasts with Pearce's finding that safety is emphasised more by tourists with less travel experience (Pearce, 2005). The explanation for this finding may be that returning tourists to a specific destination such as Denmark are subject to some kind of selection mechanism of tourists that prioritise safety. This may reflect a difference between measuring travel experience in general, as Pearce did, and travel experience with a specific destination.

Table 2. Number of nights ${ }^{\#}$ the tourists have spent in Denmark for the last five years and percentage motivated by safety

\begin{tabular}{|l|l|l|l|}
\hline Segment of the market & \multicolumn{3}{l|}{ Percentage motivated by safety (\%) } \\
\hline & 2004 & 2008 & 2011 \\
\hline No nights in Denmark for the last five years & 48.3 & 44.7 & 48.1 \\
\hline 1-5 nights in Denmark for the last five years & 60.5 & 62.3 & 70.2 \\
\hline More than 5 nights for the last five years & 63.4 & 60.3 & 58.8 \\
\hline Total & 59.4 & 59.1 & 61.1 \\
\hline
\end{tabular}

Note. \#: the number does not include the nights at the current holiday.

A $\chi^{2}$ test of the correlation between whether tourists have had at least one night in Denmark for the last five years and whether they are motivated by safety results in the test-value 78,8 in 2004, 124.1 in 2008 and 124.5 in 2011. For all three years, the p-value is significantly less than $1 \%$, which means that the correlation is statistically significant at a $1 \%$-level (reflecting that the more experienced you are with travelling to Denmark the higher you weigh safety).

Source: Estimations based on VisitDenmark's tourist survey 2004, 2008 and 2011.

The analysis also shows some differences between accommodation forms. Table 3 shows that 
tourists accommodated at holiday centres, campsites and in rented holiday homes ascribe the highest weight to safety in all three years while tourists at hotels and youth hostels weigh safety less. When we use holiday centres as a reference group, a statistical test reveals that tourists sleeping at hotels (both 2004 and 2011) and youth hostels are significantly less motivated by safety while tourists at rented holiday homes are more motivated by safety (both 2008 and 2011). The result may reflect Plog's tourist types (1974) according to which the psycho-centric tourists seek destinations similar to their home environment to feel more safe and secure while allocentric tourists are willing to accept a high level of risks.

Table 3. Forms of accommodation, type of travel group, age groups and percentage motivated by safety when visiting Denmark

\begin{tabular}{|c|c|c|c|}
\hline \multirow[t]{2}{*}{ Segment of the market } & \multicolumn{3}{|c|}{ Percentage motivated by safety $(\%)$} \\
\hline & 2004 & 2008 & 2011 \\
\hline \multicolumn{4}{|l|}{ Forms of accommodation: } \\
\hline - Hotel & $50.9 *$ & 55.3 & $46.5^{*}$ \\
\hline - $\quad$ Holiday centre (ref.) & 64.9 & 57.8 & 63.0 \\
\hline - Youth hostel & $49.9^{*}$ & $31.5 *$ & $46.4^{*}$ \\
\hline - Camping & 64.8 & 60.5 & 59.1 \\
\hline - $\quad$ Rented holiday homes & 62.2 & $65.1 *$ & $80.2 *$ \\
\hline \multicolumn{4}{|l|}{ Type of travel group } \\
\hline - $\quad$ Single travellers (ref.) & 48.0 & 39.6 & 44.3 \\
\hline - Two persons with no children & $61.6^{*}$ & $62.9 *$ & $65.2 *$ \\
\hline - $\quad$ Family with children & $61.1 *$ & $59.7 *$ & $62.6^{*}$ \\
\hline - $\quad$ Larger groups $(>3)$ with no children & $66.8^{*}$ & $66.8 *$ & $55.6 *$ \\
\hline \multicolumn{4}{|l|}{ Age groups } \\
\hline - $15-25$ years & $35.6^{*}$ & $40.7 *$ & $48.2 *$ \\
\hline - 26-36 years & $56.8^{*}$ & $55.9 *$ & $53.0 *$ \\
\hline - $36-45$ years & $58.1 *$ & $55.3 *$ & $59.5^{*}$ \\
\hline - $46-55$ years & $58.5^{*}$ & $57.3 *$ & $60.4^{*}$ \\
\hline - $\quad$ 56-65 years (ref.) & 65.5 & 69.6 & 70.9 \\
\hline - 66 years or more & 65.7 & $59.6 *$ & $57.1^{*}$ \\
\hline Total & 59.4 & 59.1 & 61.1 \\
\hline
\end{tabular}

Note. *A $\chi^{2}$ test reveals that for forms of accommodations marked with an asterisk, the percentage motivated by safety is significantly different than for the reference group "holiday centre". Regarding "travel group", the $\chi^{2}$ test reveals that for the types of travel group marked with an asterisk, the percentage motivated by safety is significantly different than for the reference group "single travellers". Regarding "age group", the $\chi^{2}$ test reveals that for age groups with an asterisk, the percentage motivated by safety is significantly different than for the reference group 56-65 years.

Source: Estimations based on VisitDenmark's tourist survey 2004, 2008 and 2011. 
Table 3 also shows that single travellers ascribe less weight to safety than any other travel group. In 2004 and 2008 safety is most important for large travelling groups with no children. Being part of a travelling group may be one way of reducing uncertainty. In 2011 safety is most important for two persons with no children. Table 3 further shows that the age of the tourist may influence how important safety is as a motivation factor. It is not that important for people below the age of 26 while it is most important for people between 56-65 years.

Finally, we examine whether there are differences in the weight ascribed to safety between tourists going on a city holiday and tourists travelling to more rural areas. This point can be illustrated by examining the location of the tourists' accommodation. The geographical dimension used in the analysis is municipalities. We define four areas: "the Copenhagen area", including the municipality of Copenhagen and surrounding municipalities; "city areas", which are municipalities dominated by a large city but located outside Copenhagen; "west coast areas", which are municipalities with their coast line to the North Sea in the Western part of Denmark, typically with no major city but many tourists; and finally, "rural areas", which are municipalities with no large city and located in the hinterland of the coast and only few tourists.

The main result is that tourists visiting coastal and rural areas find safety more important than tourists in city and Copenhagen areas. At the overall level, a $\chi^{2}$ test reveals that there is significant statistical difference in how safety influences on the choice of visiting coastal and rural or city areas. The findings may be explained by the fact that tourists travelling to coastal and rural areas are motivated by safety. Consequently, they choose destinations in Denmark where they expect to find safety, which is most often in the coastal and rural areas. In contrast, tourists visiting the city areas are less focused on safety and thus also prepared to run the risks of city life. One may claim that the balance of exploration and safety is in this situation more in favour of exploration than for other tourists. It is remarkable that tourists visiting the Copenhagen area are actually very motivated by safety compared to other city areas.

Table 4. Regions in Denmark visited by the tourists and percentage motivated by safety when visiting Denmark

\begin{tabular}{|l|l|l|l|}
\hline Destination type & Segment of the market (counties) & \multicolumn{2}{|l|}{ Percentage motivated by safety (\%) $\mathbb{~}$} \\
\hline \multirow{3}{*}{ Coast and rural areas } & & 2008 & 2011 \\
\cline { 2 - 4 } & The West coast area & 67.9 & 77.6 \\
\cline { 2 - 4 } & Rural areas & 52.7 & 51.4 \\
\hline \multirow{2}{*}{ City areas } & City areas outside Copenhagen & 36.8 & 47.0 \\
\cline { 2 - 4 } & Copenhagen area & 56.8 & 49.4 \\
\hline Total & & 59.1 & 61.1 \\
\hline
\end{tabular}

Note. a Because of changes in the municipality and county structure in Denmark in 2007, it is not possible to calculate comparable figures for 2004. A $\chi^{2}$ test of the correlation between whether tourists have visited a rural or city area and whether they are motivated by safety results in the test-value 94.2 in 2008 and 219.1 in 2011 and in both years p-values significantly less than $1 \%$, which means that the correlation is statistically significant at $1 \%$-level.

Source: Estimations based on VisitDenmark's tourist survey 2008 and 2011. 
The results for areas visited are in keeping with the results for accommodation forms since holiday centres, campsites and rented holiday homes are most often placed in coastal and rural areas while hotels and youth hostels are typically found in the cities. Thus, the places of accommodation and locations of the holiday are highly correlated and seem to measure the same aspects. However, the result is interesting because one could claim that in destinations less predictable than Denmark, staying at hotels could be seen as the refuge for tourists because hotels and/or hotel resorts are more predictable and safer than other forms of accommodation.

Table 5. Logistic regression of tourists motivated by safety in the choice of Denmark as destination, 2011

\begin{tabular}{|c|c|c|c|c|}
\hline & \multicolumn{2}{|l|}{ Model 1} & \multicolumn{2}{|c|}{ Model 2 final model } \\
\hline & $\begin{array}{l}\text { Odds ratio } \\
\text { estimate }\end{array}$ & $\begin{array}{l}\text { Coefficient } \\
\text { estimate }\end{array}$ & $\begin{array}{l}\text { Odds ratio } \\
\text { estimate }\end{array}$ & $\begin{array}{l}\text { Coefficient } \\
\text { estimate }\end{array}$ \\
\hline Denmark & 0.442 & $-0.817 * * *$ & 0.417 & $-0.955 * * *$ \\
\hline Belgium & 1.414 & 0.347 & & \\
\hline Finland & 0.621 & -0.476 & & \\
\hline France & 1.202 & 0.184 & & \\
\hline \multicolumn{5}{|l|}{ Germany (ref. group) } \\
\hline Netherlands & 1.235 & $0.211^{*}$ & & \\
\hline Italy & 1.630 & $0.489 *$ & 1.532 & $0.427 *$ \\
\hline Japan & 2.332 & $0.847 * * *$ & 2.203 & $0.790 * * *$ \\
\hline Norway & 1.163 & 0.151 & & \\
\hline Poland & 0.762 & -0.272 & & \\
\hline Switzerland & 0.973 & -0.028 & & \\
\hline Spain & 0.860 & -0.151 & & \\
\hline Sweden & 1.009 & 0.008 & & \\
\hline UK & 1.172 & 0.159 & & \\
\hline USA & 1.834 & $0.607 * * *$ & 1.728 & $0.547 * * *$ \\
\hline Other Europe & 1.124 & 0.117 & & \\
\hline Rest of world & 2.271 & $0.820 * * *$ & 2.145 & $0.763 * * *$ \\
\hline Prior experience with DK & 2.762 & $1.016 * * *$ & 2.770 & $1.019 * * *$ \\
\hline Prior experience with $\mathrm{DK}^{2}$ & 0.853 & $-0.159 * * *$ & 0.852 & $-0.161 * * *$ \\
\hline Age level & 1.004 & $0.004 * *$ & 1.005 & $0.005 * *$ \\
\hline \multicolumn{5}{|l|}{ Single travellers (ref.) } \\
\hline Two persons with no children & 1.923 & $0.654 * * *$ & 1.939 & $0.662 * * *$ \\
\hline Family with children & 1.698 & $0.530 * * *$ & 1.706 & $0.534 * * *$ \\
\hline Larger groups with no children & 1.227 & $0.204 *$ & 1.229 & $0.206^{*}$ \\
\hline \multicolumn{5}{|l|}{ Holiday centre (ref. group) } \\
\hline Hotel & 0.590 & $-0.528 * * *$ & 0.569 & $-0.564 * * *$ \\
\hline Youth hostel & 0.724 & $-0.322 * *$ & 0.697 & $-0.361 * * *$ \\
\hline Camping & 1.037 & 0.036 & & \\
\hline Rented holiday home & 1.659 & $0.506^{* * *}$ & 1.578 & $0.456 * * *$ \\
\hline \multicolumn{5}{|l|}{ Coastal areas (ref. group) } \\
\hline Rural areas & 0.496 & $-0.702 * * *$ & 0.497 & $-0.698 * * *$ \\
\hline City areas & 0.555 & $-0.588 * * *$ & 0.567 & $-0.567 * * *$ \\
\hline Copenhagen areas & 0.650 & $-0.431 * * *$ & 0.647 & $-0.435 * * *$ \\
\hline $\mathrm{R}^{2}$ max rescaled & 0.2021 & 0.2021 & 0.2003 & 0.2003 \\
\hline $\mathrm{N}$ & 7,551 & 7,551 & 7,551 & 7,551 \\
\hline
\end{tabular}

Note. * Statistical significant at the $10 \%$-level, ** significant at the 5\%-level, *** significant at the $1 \%$-level; Intercept not shown. 
In Table 5, a statistical model is set up. The model shows an overall picture of which tourists' characteristics have the most influence on being motivated by safety. The safety variable is binary scaled and accordingly the models estimated in table 5 are based on logistic regressions. The models are estimated by the statistical program SAS. The second and fourth columns present the estimated models while the first and third columns depict the odds ratio. In the estimated models, a positive sign indicates that safety is emphasized more. The odds ratios higher than 1 show that more are concerned with safety than in the reference group and for odds ratio less than 1 the opposite situation is the case. In the multivariate analysis, some factors have insignificant effects, meaning that they are excluded from the final model (model 2) showing only the robust, stable and significant factors that influence safety. Overall, the results of the logistic regression show that belonging to a specific nationality influences on being motivated by safety when visiting Denmark, but also other factors influence the probability to be motivated by safety, including age level, type of travel group, and accommodation type and area. In contrast, having prior experience with Denmark does not influence on being motivated by safety.

\section{Conclusion}

Our main research question was: What determines the choice of tourist destination? We answered this question in the following way. First, Section 2 presented research on safety and choice of destination. Second, Section 3 introduced the method and the data from VisitDenmark's tourist survey, which contains information about Danish and foreign tourists in Denmark and their motivation, activities, profiles, and so on.

Next, Section 4 presented the empirical results. Our analysis showed that the most important motivation factor for tourists to choose Denmark as a destination was the feeling of safety. Safety was mentioned by $61 \%$ of the tourists in the 2011-survey, and is therefore the most important motivation factor for choosing Denmark as a holiday destination. This result is in line with a study from Taiwan in which personal safety was also ranked very high (second) among factors influencing foreigners' choice of destination (Hsu et al., 2009).

The results also showed some differences between nationalities and accommodation forms. It was found that Danes and tourists from countries close to Denmark attach high importance to safety, but it is also important for nationalities such as Americans and Japanese. Tourists staying at hotels and youth hostels ascribed less weight to safety than tourists using other accommodation forms. This parallels results from the analysis of city versus rural destinations, in which it was found that tourists on city holidays ascribe less weight to safety than tourists in rural areas. Finally, we also found that age level and type of travel group influence on being motivated by safety. Overall, the results fit quite nicely with the popular perception of Denmark as the fairy tale country where Hans Christian Andersen was born and where a policeman will stop the traffic to let a duck family pass. In perspective, future research should try to establish whether these empirical results on safety from Denmark can be generalised to other countries. 


\section{Acknowledgement}

An earlier version of this paper was presented at the annual Socioeconomic Conference in Amsterdam, Holland, October 28-29, 2016. We thank the other participants for helpful comments.

\section{References}

Bianchi, C. (2015). Solo Holiday Travellers: Motivators and Drivers of Satisfaction and Dissatisfaction. International Journal of Tourism Research. Published online in Wiley Online Library (wileyonlinelibrary.com). https://doi.org/10.1002/jtr.2049

Brandt, U. S., \& Svendsen, G. T. (2010). The survival of the Nordic welfare state and social trust. Nordic Journal of Political Economy, 36, 1-15.

Canally, C., \& Timothy, D. J. (2007). Perceived Constraints to Travel across the US-Mexico Border among American University Students. International Journal of Tourism Research, 9, 423-437. https://doi.org/10.1002/jtr.614

Crompton, S. L. (1979). Motivations of Pleasure Vacation. Annals of Tourism Research, 6, 408-424. https://doi.org/10.1016/0160-7383(79)90004-5

EUROSTAT. (2013). Key figures on Europe 2013 digest of the online Eurostat yearbook. European Union, EUROSTAT Pocketbooks.

Garg, A. (2015). Travel Risks vs Tourist Decision Making: A Tourist Perspective. International Journal of Hospitality \& Tourism Systems, 8, 1-9.

Goeldner, C. R., \& Ritchie, J. R. B. (2006). Tourism: Principles, Practices, Philosophies. Hoboken: John Wiley \& Sons.

Hsu, T. Z., Tsai, Y. F., \& Wu, H. H. (2009). The Preference Analysis for Tourist Choice of Destination: A Case Study. Tourism Management, 30, 288-297. https://doi.org/10.1016/j.tourman.2008.07.011

Jensen, S., \& Svendsen, G. T. (2016). Social Trust, Safety and the Choice of Tourist Destination. Business and Management Horizons, 4, 1-9. https://doi.org/10.5296/bmh.v4i.9232

Kozak, M., Crotts, J. C., \& Law, R. (2007). The Impact of the Perception of Risk on International Travellers. International Journal of Tourism Research, 9, 233-242. https://doi.org/10.1002/jtr.607

Malhotra, N. K., Birks, D., \& Wills, P. (2012). Marketing Research. An Applied Approach (4th edition). White plains, NY: Pearson Education Limited.

Mansfeld, Y., \& Pizam, A. (eds.) (2006). Tourism, Security and Safety: From Theory to Practice. Oxford: Butterwoth-Heinemann.

Page, S., \& Connell, J. (2006). Tourism: A Modern Synthesis (2nd edition). Stamford, Connecticut: Thomson Learning. 
Pearce, P. L. (2005). Tourist Behavior: Themes and Conceptual Schemes. Clevedon: Channel View Publications.

Pearce, P. L., \& Lee, U. I. (2005). Developing the Travel Career Approach to Tourist Motivation. Journal of Travel Research, 43, 226-237. https://doi.org/10.1177/0047287504272020

Pennington-Gray, L., \& Schroeder, A. (2013). International Tourist's Perception of Safety and Security: The Role of Social Media. Matkailututkimus, 9, 7-23.

Pisonero, R. D. (2015). Tourist Activity and Low Cost Airlines in the Mediterranean Spanish Arch. International Journal of Social Science Research, 3, 13-28. https://doi.org/10.5296/ijssr.v3i1.6866

Pizam, A., \& Mansfeld, Y. (2006). Toward a Theory of Tourism Security. In Y. Mansfeld \& A. Pizam (Eds.), Tourism, Security and Safety: From Theory to Practice (pp. 1-27). Oxford: Butterwoth-Heinemann.

Plog, S. (1974). Why Destination Areas Rise and Fall in Popularity. Cornell Hotel and Restaurant Administration Quarterly, February, 55-58.

Sirakaya, E., \& Woodside, A. G. (2005). Building and Testing Theories of Decision Making by Travellers. Tourism Management, 26, 815-832. https://doi.org/10.1016/j.tourman.2004.05.004

Svendsen, G. L. H., \& Svendsen, G. T. (2016). Trust, Social Capital and the Scandinavian Welfare State: Explaining the Flight of the Bumblebee. Cheltenham, UK: Edward Elgar. https://doi.org/104337/9781785365584

Tasci, A. D. A., \& Boylu, Y. (2010). Cultural Comparison of Tourists' Safety Perception in Relation to Trip Satisfaction. International Journal of Tourism Research, 12, 179-192. https://doi.org/10.1002/jtr.745

United Nations. (2014). Population and Vital Statistics Report, Statistical Papers, Series A, vol. LXVI. Department of Economic and Social Affairs.

VisitDenmark. (2013). Turismens økonomiske betydning i Danmark 2011. Copenhagen: VisitDenmark, Viden \& Analyse.

Weaver, D., \& Lawton, L. (2006). Tourism Management (3rd edition). Milton: John Wiley \& Sons, Australia, Ltd.

Wilks, J., \& Page, S. (2003). Managing Tourist Health and Safety. Oxford: Elsevier.

Yang, E. C. L., Sharif, S. P., \& Khoo-Lattimore, C. (2015). Tourist's Risk Perception of Risky Destinations: The Case of Sabah's Eastern Coast. Tourism and Hospitality Research, 15, 206-211. https://doi.org/10.1177/1467358415576085 


\section{Copyright Disclaimer}

2017, Vol. 5, No. 2

Copyright for this article is retained by the author(s), with first publication rights granted to the journal.

This is an open-access article distributed under the terms and conditions of the Creative Commons Attribution license (http://creativecommons.org/licenses/by/3.0/). 